\title{
On the clot-promoting activity of human platelets in a one-stage prothrombinase assay
}

Citation for published version (APA):

Bevers, E. M., Comfurius, P., Hemker, H. C., \& Zwaal, R. F. A. (1982). On the clot-promoting activity of human platelets in a one-stage prothrombinase assay. Haemostasis, 12(3), 268-274.

https://doi.org/10.1159/000214682

Document status and date:

Published: 01/01/1982

DOI:

10.1159/000214682

Document Version:

Version created as part of publication process; publisher's layout

\section{Please check the document version of this publication:}

- A submitted manuscript is the version of the article upon submission and before peer-review. There can be important differences between the submitted version and the official published version of record.

People interested in the research are advised to contact the author for the final version of the publication, or visit the DOI to the publisher's website.

- The final author version and the galley proof are versions of the publication after peer review.

- The final published version features the final layout of the paper including the volume, issue and page numbers.

Link to publication

\footnotetext{
General rights rights.

- You may freely distribute the URL identifying the publication in the public portal. please follow below link for the End User Agreement:

www.umlib.nl/taverne-license

Take down policy

If you believe that this document breaches copyright please contact us at:

repository@maastrichtuniversity.nl

providing details and we will investigate your claim.
}

Copyright and moral rights for the publications made accessible in the public portal are retained by the authors and/or other copyright owners and it is a condition of accessing publications that users recognise and abide by the legal requirements associated with these

- Users may download and print one copy of any publication from the public portal for the purpose of private study or research.

- You may not further distribute the material or use it for any profit-making activity or commercial gain

If the publication is distributed under the terms of Article $25 \mathrm{fa}$ of the Dutch Copyright Act, indicated by the "Taverne" license above, 


\title{
On the Clot-Promoting Activity of Human Platelets in a One-Stage Prothrombinase Assay
}

\author{
E.M. Bevers, P. Comfurius, H.C. Hemker, R.F.A. Zwaal \\ Biomedical Center, University of Limburg, Department of Biochemistry, Maastricht, The Netherlands
}

Key Words. Platelets · Coagulation · Prothrombinase factor V · Phospholipids . Platelet factor 3 (PF 3)

Abstract. The procoagulant activity of activated platelets in a one-stage prothrombinase assay is reevaluated. It is shown that the apparent procoagulant activity of platelets activated by ADP or collagen can be explained by minor cell lysis accompanying platelet activation. The reduction in clotting time observed with thrombin activated platelets can be explained by a combined effect of minor cell lysis and release and activation of factor $\mathrm{V}$ from the platelets. Platelets stimulated by ionophore A23187 or by the combined action of collagen plus thrombin show a much shorter clotting time than can be accounted for by minor platelet lysis or release and activation of factor $\mathrm{V}$ from the platelets.

The results with this clotting assay essentially confirm previous observations [Bevers et al.: Eur. J. Biochem. 122: 429-436, 1982] using a spectrophotometric method with highly purified coagulation factors and a chromogenic substrate to measure the rate of thrombin formation with activated platelets.

\section{Introduction}

The ability of activated platelets to reduce the clotting time in coagulation assays that are sensitive to procoagulant phospholipids has been well established [1-3]. However, clotting assays in the presence of platelets are known to be sensitive to low percentages of cell lysis [3], and to release and activation of factor $\mathrm{V}$ from the platelets [4]. We have recently shown, using a chromogenic substrate assay with highly purified coagulation factors, that platelets stimulated by the combined action of collagen plus thrombin strongly increase the rate of factor $\mathrm{X}$ and prothrombin activation, as compared to nonac- 



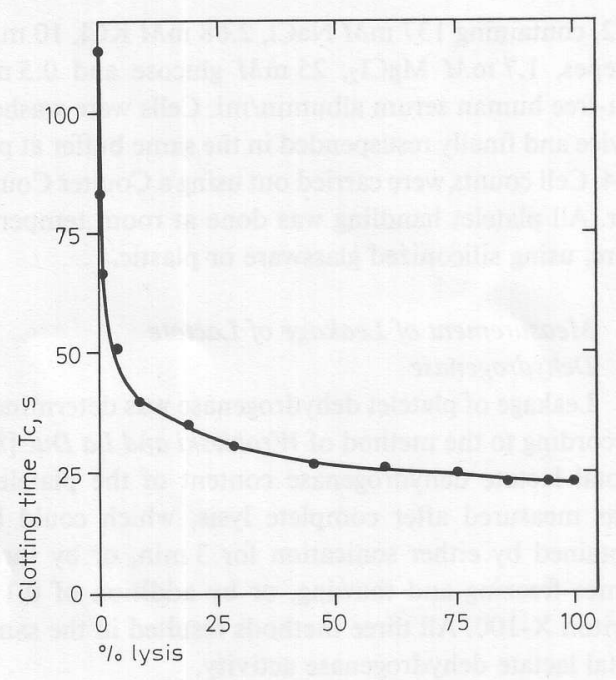

Fig. 1. Clotting time of sonicated platelets as a function of percentage lysis produced by sonication. Clotting was measured in the absence of added factor $\mathrm{Va}$ (see text). The longest clotting time shown (114 s) corresponds to $0.4 \%$ of lysis; non sonicated platelets had a clotting time of $178 \mathrm{~s}$. Data are shown for one representative platelet preparation.

\section{Results}

Figure 1 shows the relationship between the clotting time (in the absence of excess added factor $\mathrm{Va}$ ) and the amount of platelet lysis. Platelet lysis was induced by sonication of washed platelet suspensions for various time periods at a minimal output of the sonifier. Lysis, measured by the activity of lactate dehydrogenase in the supernatant, was expressed as a percentage of this enzyme activity in a completely lysed platelet preparation. Addition of intact platelets to the assay system hardly affects the clotting time (see also table I) although this might differ from one platelet preparation to another, depending on the amount of lysed platelets already present in the nonsonicated preparation. Trace amounts of lysed platelets induce a significant decrease in clotting time. A nonlinear relationship between clotting time and platelet lysis is obtained. The decrease in clotting time produced by $1 \%$ lysis in the platelets is more than half of that observed with a completely lysed platelet preparation. A similar nonlinear relationship (with shorter clotting times) was obtained in the presence of an excess of exogenously added factor Va (compare table I).

The effect of a 10-min activation period with different agonists on the procoagulant activity of intact washed human platelets is given in table I. Platelets contain factor V which can be released and activated as a result of the action of some platelet agonists [13-15]. Because factor Va is a cofactor in the activation of prothrombin, this might interfere with the coagulation assay. Therefore, the assay was carried out either in the absence or in the presence of exogenously added excess of factor $\mathrm{Va}$. As a result of the addition of factor $\mathrm{Va}$, the rate of thrombin formation will be increased leading to a decrease in clotting time. Also, the blank clotting time with buffer instead of platelets is significantly lowered in the presence of added factor Va. Addition of nonstimulated platelets hardly affects the blank clotting time, either with or without added factor $\mathrm{Va}$ in the assay. Since minor amounts of platelet lysis strongly shorten the clotting time and some platelet lysis accompanies platelet activation, it will be clear that for an evaluation of the clot-promoting effect of activated platelets a control for the contribution of lysed cells in the assay is an essential requirement.

When platelets stimulated by ADP or collagen are used in the clotting assay (either in the presence or absence of exogenously added 
Table I. Percentage of lysis in and clotting time of sonicated and activated platelets

\begin{tabular}{|c|c|c|c|}
\hline \multirow{2}{*}{$\begin{array}{l}\text { Sonication time, or platelet activator } \\
\text { (final concentration) }\end{array}$} & \multirow{2}{*}{$\begin{array}{l}\text { Lysis } \\
\%\end{array}$} & \multicolumn{2}{|l|}{ Clotting time, $s$} \\
\hline & & $\begin{array}{l}\text { absence of } \\
\text { excess factor } \mathrm{Va}\end{array}$ & $\begin{array}{l}\text { presence of } \\
\text { excess factor } \mathrm{Va}\end{array}$ \\
\hline Buffer & - & 193 & 115 \\
\hline Platelets (not activated or sonicated) & - & 189 & 98 \\
\hline 1s sonication & 1.7 & 79 & 49 \\
\hline $3 \mathrm{~s}$ sonication & 5.1 & 57 & 38 \\
\hline $6 \mathrm{~s}$ sonication & 11.9 & 44 & 31 \\
\hline $10 \mathrm{~s}$ sonication & 19.2 & 38 & 27 \\
\hline $12 \mathrm{~s}$ sonication & 24.9 & 35 & 25 \\
\hline 3 min sonication & 100 & 23 & 18 \\
\hline $\operatorname{ADP}(10 \mu M)$ & 1.1 & 90 & 54 \\
\hline Collagen $(10 \mu \mathrm{g} / \mathrm{ml})$ & 1.9 & 76 & 48 \\
\hline Thrombin $(2 \mathrm{n} M)$ & 1.7 & 57 & 49 \\
\hline Collagen + thrombin & 1.6 & 35 & 29 \\
\hline $\mathrm{A} 23187(3 \mu M)$ & 2.7 & 27 & 23 \\
\hline
\end{tabular}

Due to minor variations in the amount of lysis, data are given for one representative platelet preparation. In total, 17 platelet preparations were tested that with two exceptions all showed a similar behavior.

factor $\mathrm{Va}$ ), the reduction in clotting time closely corresponds to that of sonicated preparations that show the same amount of lysis as produced during the activation procedure. Similar results were obtained with platelets activated with serotonin, epinephrine or kaolin (data not shown). Without added factor $\mathrm{Va}$ in the clotting assay, thrombin-activated platelets show a shorter clotting time than can be accounted for by lysis, but this discrepancy disappears in the presence of an excess of exogenous factor Va. This strongly suggests that in the absence of added factor Va the reduction in clotting time is not only caused by minor cell lysis (some $1.7 \%$ ) but also by release and activation of factor $\mathrm{Va}$. It should be noted here that according to the data of Chesney et al. [15], $0.1 \mathrm{ml}$ of platelets $\left(10^{8}\right.$ cells $\left./ \mathrm{ml}\right)$ used in the assay can contribute approximately 1 unit of factor $\mathrm{V}$ when this factor is fully released and activated into factor Va. The small amount of thrombin used to activate the platelets does not significantly affect the clotting time in this assay system. In contrast to the platelet activations described above, platelets stimulated by A23187 or by the combined action of collagen plus thrombin produce a much shorter clotting time (both in the absence or presence of added factor $\mathrm{Va}$ ) than can be accounted for by minor cell lysis and/or release and activation of factor $\mathrm{V}$ from the platelets. 


\section{Discussion}

The clotting time observed in a one-stage prothrombinase assay using Russell's viper venom will be dependent on the availability of negatively charged procoagulant phospholipids for the formation of the prothrombinase complex [16]. In the platelet plasma membrane, the negatively charged phospholipids are almost exclusively present in the inner leaflet of the membrane $[17,18]$. This explains why a preparation of intact nonstimulated platelets does not significantly shorten the clotting time. Platelet damage, leading to the exposure of the inner surface of the plasma membrane, thereby offering a negatively charged phospholipid surface for the formation of the prothrombinase complex, results in a decrease in clotting time.

Lowering of the clotting time by the addition of activated platelets in the coagulation assay can have at least three different explanations: (i) release and activation of factor $\mathrm{V}$ from the platelet $\alpha$-granules since the plasma mixture offered in the coagulation assay normally does not contain an excess of this factor and hence is sensitive to the addition of factor Va; (ii) exposure of the negatively charged inner surface of the platelet plasma membrane as a result of lysis caused by the activation procedure; (iii) exposure of negatively charged phospholipids at the platelet outer surface as a result of rearrangements in the plasma membrane caused by the agonistreceptor interaction. The data presented here show that the decrease in clotting time caused by ADP or collagen-activated platelets can be explained by platelet lysis. It should be emphasized, however, that lysis was measured by the activity of the cytoplasmic enzyme lactate dehydrogenase in the platelet supernatant after activation. Therefore, it cannot be excluded that the presence of this enzyme in the supernatant is a result of a transient leakage and does not necessarily reflect platelet damage and exposure of the inner surface of the plasma membrane. However, the close correlation in clotting time between platelets lysed by sonication and platelet lysis produced by certain agonists strongly suggests that percentage leakage of lactate dehydrogenase during platelet activation in fact reflects percentage of cell damage.

The effect of release and activation of factor $\mathrm{V}$ from the platelet granules can be of importance only in those cases where platelets are activated by thrombin or a combination of another agonist with thrombin. This can be seen in table I comparing the reduction in clotting time between platelets activated with collagen and platelets activated with thrombin. In the absence of exogenously added extra factor Va the assay will be sensitive to factor $\mathrm{Va}$ from the platelets. Although activation by collagen results in a similar percentage of lysis as activation by thrombin, the clotting time observed with thrombinactivated platelets is shorter than that observed with collagen-activated platelets. This can be explained by the release and activation of factor $\mathrm{V}$ from the platelets which occurs upon activation with thrombin. (Collagen only induces release but not activation of factor V.) When an excess of factor $\mathrm{Va}$ is added to the assay, the difference in clotting time between collagen- and thrombin-activated platelets disappears, and equals that of sonicated preparations showing the same amount of lysis.

Addition of platelets activated by a combination of collagen plus thrombin produces an even further reduction in clotting time, which cannot be explained by either cell lysis or release and activation of factor $\mathrm{V}$. It has 
been shown previously that this activation procedure exposes negatively charged phospholipids (particularly phosphatidylserine) at the cell outer surface, as a result of transbilayer movement of phospholipids by a process not involving lysis of the cells [5]. It is suggested that this process is in fact mainly responsible for the observed reduction of the clotting time with platelets activated by collagen plus thrombin. A similar explanation can be given for platelets activated by ionophore A23187.

It should be mentioned that the concentrations of the agonists used were all sufficient to produce optimal release and aggregation, i.e no increase in $\alpha$-granula or dense body release or in the extent of aggregation was observed upon increasing the agonist concentration. Also, the effect of the combined action of collagen plus thrombin could not be evoked by using higher thrombin concentrations to activate the platelets, or combinations of thrombin with other agonists.

The data obtained with this clotting assay are in close agreement with those obtained using an assay system with purified coagulation factors and a chromogenic substrate to measure the rate of thrombin formation in the presence of activated platelets [5]. Although care must be taken with the interpretation of clotting times with respect to lysis of the platelets or release and activation of factor $\mathrm{V}$, the assay described here is suitable to determine whether or not negatively charged phospholipids become exposed at the platelet outer surface as a result of activation by a platelet agonist.

\section{References}

1 Spaet, T.H.; Cintron, J.: Studies on platelet factor3 activity. Br. J. Haemat. 11: 269-275 (1965).
2 Hardisty, R.M.; Hutton, R.A.: Platelet aggregation and the availability of platelet factor 3 . Br. J. Haemat. 12: 764-776 (1966).

3 Joist, J.H.; Dolezel, G.; Lloyd, J.V.; KinloughRathbone, R.L.; Mustard, J.F.: Platelet factor-3 availability and the platelet release reaction. J. Lab. clin. Med. 1974: 474-482.

4 Van Zutphen, H.; Bevers, E.M.; Hemker, H.C.; Zwaal, R.F.A.: Contribution of the platelet factor $\mathrm{V}$ content to platelet factor 3 activity. Br. J. Haemat. 45: 121-131 (1980).

5 Bevers, E.M.; Comfurius, P.; Rijn, J.L.M.L. van; Hemker, H.C.; Zwaal, R.F.A.: Generation of platelet prothrombin converting activity and the exposure of phosphatidylserine at the platelet outer surface. Eur. J. Biochem. 122: 429-436 (1982).

6 Bevers, E.M.; Dieijen, G. van; Rosing, J.; Hornstra, G.; Zwaal, R.F.A.: The effect of prostacyclin on the participation of platelets in factor $\mathrm{X}$ activation and thrombin formation (Abstract). Thromb. Haemostasis 46: 271 (1981).

7 Rosing, J.; Tans, G.; Govers-Riemslag, J.W.P.; Zwaal, R.F.A.; Hemker, H.C.: The role of phospholipids and factor $\mathrm{Va}$ in the prothrombinase complex. J. biol. Chem. 255: 274-283 (1980).

8 Wroblewski, F.; La Due, J.S.: Lactic dehydrogenase activity in blood. Proc. Soc. exp. Biol. Med. 90: 210-215 (1955).

9 Tans, G.; Zutphen, H. van; Comfurius, P.; Hemker, H.C.; Zwaal, R.F.A.: Lipid phase transitions and procoagulant activity. Eur. J. Biochem. 95: 449-457 (1979).

10 Esmon, C.T.: The subunit structure of thrombin activated factor $\mathrm{V}$. Isolation of activated factor $\mathrm{V}$, separation of subunits and reconstitution of biological activity. J. biol. Chem. 254: 964-974 (1979).

11 Kappeler, R.; Das Verhalten von Faktor V im Serum unter normalen und pathologischen Bedingungen. Z. klin. Med. 153: 103-113 (1955).

12 Nesheim, M.E.; Myrmel, K.H.; Hibbard, L.; Mann, K.G.: Isolation and characterization of single chain bovine factor V. J. biol. Chem. 254: 508517 (1979).

13 Breederveld, K.; Giddings, J.C.; Ten Cate, J.W.; Bloom, A.L.: The localization of factor $\mathrm{V}$ within normal human platelets and the demonstration of a platelet-factor $\mathrm{V}$ antigen in congenital factor $\mathrm{V}$ deficiency. Br. J. Haemat. 29: 405-412 (1975). 
14 Østerud, B.; Rapaport, S.I.; Lavine, K.K.: Factor $\mathrm{V}$ activity of platelets: Evidence for an activated factor $\mathrm{V}$ molecule and for a platelet activator. Blood 49: 819-834 (1977).

15 Chesney, C.M.; Pifer, D.; Colman, R.W.: Subcellular localization and secretion of factor $\mathrm{V}$ from human platelets. Proc. natn. Acad. Sci. USA 78: 5180-5184 (1981).

16 Zwaal, R.F.A.: Membrane and lipid involvement in blood coagulation. Biochim. biophys. Acta 515: 163-205 (1978).

17 Chap, H.J.; Zwaal, R.F.A.; Deenen, L.L.M. van: Action of highly purified phospholipases on blood platelets. Evidence for an asymmetric distribution of phospholipids in the surface membrane. Biochim. biophys. Acta 467: 146-164 (1977).
18 Perret, B.; Chap, H.J.; Douste-Blazy, L.: Asymmetric distribution of arachidonic acid in the plasma membrane of human platelets. A determination using purified phospholipases and a rapid method for membrane isolation. Biochim. biophys. Acta 556: 434-446 (1979).

Received: March 12, 1982

Accepted by Editor J. Caen: March 19, 1982

E.M. Bevers, Biomedical Center,

University of Limburg,

Department of Biochemistry, Maastricht (The Netherlands) 